\title{
Manajemen Pemupukan pada Perkebunan Kelapa Sawit (Elaeis guineensis Jacq.) Kabupaten Rokan Hulu, Riau
}

\author{
Fertilization Management on Oil Palm Plantation at Rokan Hulu, Riau
}

\author{
Wahyu Hidayat, Sudirman Yahya*
}

Departemen Agronomi dan Hortikultura, Fakultas Pertanian, Institut Pertanian Bogor (Bogor Agricultural University), Jl. Meranti, Kampus IPB Darmaga, Bogor 16680, Indonesia Telp. \& Faks.62-251-8629353 e-mail agronipb@indo.net.id *Penulis Korespondensi : syahya49@yahoo.co.id

Disetujui 11 Mei 2015 / Published online 18 Mei 2015

\begin{abstract}
The research was conductedon oil palm plantation at Rokan Hulu, Riau for three months beginning on 13 Februari 2012 to 13 Mei 2012. The research included activity concerning both technical and manajerial aspects on the position of worker,supervisor, and field assistant.The purpose of this research program was to improve technical and managerial skills. The data were gained primary data and secondary data. Primary data are all information which was gained directly from on the field covering the aspects of the right kind of fertilizer, right dosage, and right time and method of application. Secondary data was gained from office files, included climate data, productivity, fertilizer recommendation, organization structure and matters pertain to man power. The data were analyzed by using descriptive method. The result show that Tambusai Estate in general has applied the right kind of fertilizer and use the right method of application, meanwhile for the time and dosage aspects need to be improved. Mechanical method of fertilizer application was more effective and efficient compared to manual method.
\end{abstract}

Keywords: effectif method, fertization, oil Palm,

\begin{abstract}
ABSTRAK
Kegiatan penelitian dilaksanakan di Kabupaten Rokan Hulu, Riau dimulai dari tanggal 13 Februari hingga 13 Mei 2012. Kegiatan penelitian menyangkut aspek teknik dan manajerial dan menjadi karyawan harian lepas (KHL), supervisior dan asisten kebun. Kegiatan penelitian bertujuan untuk meningkatkan kemampuan teknik dan pengetahuan manajerial. Pengumpulan data yang penulis lakukan meliputi data primer dan data sekunder. Data primer meliputi segala informasi yang diperoleh di lapang yang meliputi ketepatan pemupukan, tepat dosis, tepat waktu, dan metode aplikasi. Data sekunder diperoleh dari file perusahaan, berupa data curah hujan, produktivitas, rekomendasi pemupukan, struktur organisasi, dan semua yang berkaitan dengan tenaga kerja. Data yang diperoleh dianalisis menggunakan metode deskriptif.
\end{abstract}

Kata kunci: metode efektif, pemupukan, kelapa sawit 


\section{PENDAHULUAN}

Kelapa sawit (Elaeis guineensis Jacq.) merupakan salah satu palmae yang menghasilkan minyak nabati terbesar di dunia yakni sebesar 2000-3000 kg/ha/tahun, dibandingkan dengan kelapa yang hanya mencapai 700-1000 $\mathrm{kg} / \mathrm{ha} /$ tahun (Siregar, 2006).

Kelapa sawit dapat diolah menjadi minyak sawit yang biasa dikenal sebagai Crude Palm Oil (CPO) yang berasal dari daging buah dan Palm Kernel Oil (PKO) yang berasal dari inti sawit. Minyak sawit mentah $(C P O)$ merupakan produk perkebunan yang memiliki prospek cerah di masa mendatang (Budianto, 2005). Kedua minyak tersebut dapat diolah menjadi berbagai macam produk olahan seperti margarin, minyak goreng, kosmetik, sabun, dan detergen. Selain itu, kelapa sawit juga dapat digunakan sebagai biodiesel yang merupakan energi alternatif pengganti minyak bumi.

Manfaat minyak sawit yang cukup beragam tersebut menyebabkan meningkatnya konsumsi minyak sawit sehingga juga meningkatkan permintaan produksi minyak sawit. Peningkatan konsumsi minyak sawit dapat diketahui dari semakin meningkatnya volume ekspor minyak sawit pada setiap tahun. Volume ekspor minyak sawit menunjukkan peningkatan yang cukup besar setiap tahunnya. CPO pada tahun 2008 diekspor dengan volume 18141006 ton senilai US\$14 110229 dan pada tahun 2010 meningkat dengan volume ekspor 20615958 ton senilai US\$ 12626595 (Ditjenbun, 2011).

Peningkatan produksi minyak sawit harus diimbangi oleh pertambahan luas areal perkebunan kelapa sawit dan peningkatan produksi tandan buah segar (TBS). Data luas areal dan produksi perkebunan kelapa sawit Indonesia tahun 2008-2010 umumnya mengalami peningkatan yang signifikan. Pada tahun 2008 luas areal perkebunan kelapa sawit Indonesia adalah 7363847 ha dengan produksi CPO sebesar $18 \quad 141 \quad 006$ ton dan mengalami peningkatan luas areal menjadi 8430027 ha dengan produksi CPO 20615958 ton pada tahun 2010 (Ditjenbun, 2011).

Manajemen pemupukan merupakan salah satu kegiatan pemeliharaan tanaman yang dapat meningkatkan produksi serta kualitas produk yang dihasilkan. Manajemen pemupukan penting untuk dipelajari, karena untuk menjamin kelancaran pengadaan dan pelaksanaan pemupukan agar tercapai pemupukan yang efektif dan efisien. Pemupukan juga bermanfaat untuk mendorong pertumbuhan vegetatif tanaman dan produksi tandan buah segar (TBS) secara maksimum.
Poeloengan et al. (2003) menyatakan bahwa pemupukan yang efektif dan efisien dipengaruhi oleh jenis dan dosis pupuk, cara pemberian pupuk, waktu pemupukan, tempat aplikasi, dan pengawasan dalam pelaksanaan pemupukan. Pemupukan merupakan salah satu faktor penting yang berperan untuk mencapai produktivitas yang tinggi, terutama dalam memenuhi persyaratan unsur hara. Oleh karena itu, aspek manajemen pemupukan penting untuk dipelajari agar sesuai dengan standar operasional baku yang dijalankan oleh suatu persahaan.

Kegiatan penelitian bertujuan untuk mempelajari pengelolaan pemupukan tanaman kelapa sawit pada tanaman menghasilkan, menganalisis faktor-faktor yang mempengaruhi keefektifan dan efisiensi pemupukan secara manual dan mekanis.

\section{BAHAN METODE}

Kegiatan penelitian ini dilaksanakan di perkebunan kelapa sawit di Kabupaten Rokan Hulu, Riau. Kegiatan penelitian ini dilaksanakan selama tiga bulan yang dimulai pada tanggal 13 Februari 2012 sampai 13 Mei 2012.

Kegiatan yang dilakukan oleh penulis adalah sebagai karyawan harian lepas (KHL) selama tiga minggu, kemudian bertindak sebagai pendamping mandor pada tiga minggu berikutnya, dan sebagai pendamping asisten lapang pada enam minggu berikutnya.

Kegiatan teknis yang dilakukan, selama penulis berada di lapangan meliputi kegiatan: sensus pokok, penunasan, pemupukan, pengendalian gulma, pengendalian hama dan penyakit, dan kegiatan pemanenan. Pada kegiatan manajerial, penulis mempelajari tentang fungsifungsi manajemen, meliputi tugas pokok, fungsi, kewenangan, dan tanggung jawab di tingkat mandor, Field Assistant, ditingkat jabatan yang sesuai dengan struktur organisasi di lokasi magang.

Pengumpulan data yang dilakukan meliputi pengambilan data primer dan data sekunder. Data primer merupakan data yang diperoleh secara langsung melalui pengamatan yang dilakukan oleh penulis selama berada di lapangan. Kegiatan ini meliputi sistem organisasi pemupukan, aplikasi pemupukan mulai dari penguntilan pupuk, pengangkutan dan pengeceran pupuk, ketepatan jenis dan dosis pupuk, ketepatan waktu dan cara aplikasi pemupukan, jumlah tenaga kerja dalam kegiatan pemupukan, dan gejala defisiensi hara tanaman, serta dilakukan kegiatan diskusi dengan petugas gudang, KHL, mandor, dan Field Assistant. Data sekunder 
diperoleh dari studi literatur dan mempelajari arsip kebun, laporan bulanan, laporan tahunan, serta dari dokumentasi kebun. Jenis data yang diperoleh adalah sejarah dan kondisi umum perkebunan, kondisi iklim, kondisi tanaman, organisasi manajemen perusahaan, data produksi kebun, serta data yang terkait dengan pemupukan meliputi, realisasi pemupukan SOP kebun, dan dosis rekomendasi pemupukan kebun.

Analisis data yang digunakan adalah analisis deskriptif dan analisis kuantitatif, menggunakan ukuran distributif seperti presentase dan ukuran pemusatan (rata-rata). Data kemudian akan diolah menurut kebutuhan penulisan, kemudian selanjutnya hasil dari pendekatan statistik sederhana tersebut akan disajikan dalam bentuk narasi, tabel, grafik, dan diagram sesuai kebutuhan.

\section{KONDISI UMUM KEBUN}

\section{Letak Administratif}

Perkebunan sawit terletak di Desa Tambusai Utara, Kecamatan Tambusai Utara, Kabupaten Rokan Hulu, Provinsi Riau. Batasbatas perkebunan kelapa sawit berada di sebelah utara berbatasan dengan Desa Tambusai Timur Desa Kepenuhan Barat dan Desa Kepenuhan, Sebelah Timur berbatasan dengan Desa Kepenuhan Timur, Sebelah Barat berbatasan dengan Desa Tambusai Timur dan SKPD DK IV.

\section{Keadaan Iklim dan Tanah}

Rata-rata curah hujan tahunan pada perkebunan sawit dalam kurun waktu 10 tahun terakhir (2001-2011) adalah $1918 \mathrm{~mm}$ dengan jumlah hari hujan rata-rata 117 hari. Curah hujan tertinggi umumnya terjadi pada bulan Desember (rata-rata $302 \mathrm{~mm}$ ), sedangkan curah hujan terendah terjadi pada bulan Mei dengan rata-rata curah hujan sebesar $100 \mathrm{~mm}$. Rataan Bulan Kering dan Bulan Basah selama kurun waktu 10 tahun terakhir sebesar 2.27 dan 7.54. Menurut kelas iklim Schmidth-Ferguson, keadaan iklim di perkebunan sawit termasuk dalam tipe iklim B, yaitu daerah basah dengan vegetasi hutan hujan tropika.

Areal perkebunan sawit memiliki kondisi topografi yang bervariasi cukup datar dengan kemiringan 1-3 \% seluas 11.803 ha. Derajat kemasaman tanah $(\mathrm{pH})$ perkebunan sawit adalah 4.65 - 5.30. perkebunan sawit memiliki ketinggian tempat $12 \mathrm{~m}$ di atas permukaan laut (dpl) dan suhu rata-rata tahunan berkisar antara $28^{\circ}-31^{\circ} \mathrm{C}$.
Berdasarkan kelas kesesuaian lahan untuk kelapa sawit, Tambusai Estate perkebunan sawit tergolong ke dalam kelas S2 (sesuai/suitable).

\section{Keadaan Tanaman dan Produksi}

Tanaman kelapa sawit yang dibudidayakan di Tambusai Estate adalah varietas Tenera, hasil persilangan Dura dan Pisifera, yang berasal dari Tenera Papua New Guinea (PNG), Tenera Socfindo dan Tenera Marihat (PPKS). Pola tanam yang digunakan untuk penanaman kelapa sawit di Tambusai Estate adalah pola tanam segitiga sama sisi dengan jarak tanam yang digunakan adalah $9.35 \mathrm{~m} \times 9.35 \mathrm{~m} \times 9.35 \mathrm{~m}$ dengan jarak antar barisan $7.76 \mathrm{~m}$ sehingga populasi per hektarnya 132 pokok.

\section{Pelaksanaan Penelitian}

Kegiatan magang yang dilakukan di Tambusai Estate mencakup aspek teknis dan aspek manajerial. Aspek teknis yang dilakukan meliputi kegiatan penunasan, sensus pokok, pengendalian gulma (manual dan kimiawi), pemupukan, dan pemanenan. Pelaksanaan kerja baik sebagai KHL, pendamping mandor, dan pendamping asisten lapang, di Tambusai Estate secara umum dilaksanakan 6 hari kerja dalam seminggu. Waktu setiap hari kerja rata-rata selama 9 jam yang dimulai pada pukul 06.00$12.00 \mathrm{WIB}$, istirahat selama dua jam (12.00-14.00 WIB), lalu dilanjutkan bekerja selama tiga jam dari pukul $14.00 \mathrm{sd}$. 17.00 WIB.

Pelaksanaan kegiatan magang di Tambusai Estate yang dilakukan oleh penulis, yakni sebagai KHL (Karyawan Harian Lepas), pendamping mandor, dan pendamping asisten lapang di Afdeling dilaksanakan setiap SeninSabtu mulai pukul 05.30 WIB. Penulis diwajibkan mengikuti apel pagi yang dimulai pukul 05.30 WIB bersama asisten, mandor dan KHL (Karyawan Harian Lepas).

\section{Aspek Manajerial}

Karyawan non staff. Pada saat magang selama tiga bulan di Tambusai Estate, penulis menjadi karyawan harian lepas (KHL) selama tiga minggu. Penulis bertugas sebagai penguntil pupuk, muat bongkar pupuk, dongkel anak kayu, dan sensus pokok. Setelah penulis berstatus sebagai karyawan harian lepas, penulis berstatus sebagai pendamping mandor selama tiga minggu berikutnya. Kemudian hasil dari pekerjaan tersebut dilaporkan kepada asisten lapangan 
dalam bentuk laporan harian. Laporan yang telah dibuat dapat mempermudah pengontrolan yang dilakukan oleh asisten lapangan.

Pendamping mandor panen. Setiap pagi hari, penulis membantu mandor dalam melakukan pengabsenan karyawan untuk pembagian hanca panen. Penulis juga ikut membantu mandor panen dalam menentukan kapel panen, memberikan pengarahan tentang 7 prinsip disiplin panen. Setiap sore hari penulis menghitung angka kerapatan panen (AKP) dan melakukan pemeriksaan brondolan di ketiak pokok, piringan, jalan pikul, dan gawangan bersih dikutip oleh pemanen. Berdasarkan pengamatan penulis, permasalahan yang dihadapi saat menjadi pendamping mandor panen adalah kekurangan jumlah pemanen. Selain itu, penulis juga masih menemukan brondolan yang tinggal di ketiak, piringan, dan jalan pikul. Hal ini dikarenakan pemanen lebih mengejar output sebesar tiga ton, daripada mengejar basis yang hanya satu ton. Dengan demikian, kualitas kerja pemanen belum dapat dikatakan baik Dalam satu kemandoran, rata-rata pekerja yang diawasi sebanyak 13 orang dengan luas areal \pm 70 ha.

Pendamping mandor perawatan. Penulis ikut membantu mandor perawatan dalam mengawasi pekerjaan karyawan saat rawat jalan pikul dan rawat piringan. Setelah itu, penulis juga membantu mandor perawatan mengisi laporan kerja dalam buku mandor perawatan., Rata-rata jumlah pekerja yang diawasi sebanyak 3 orang dengan luasan \pm 24 ha. Permasalahan yang dihadapi saat penulis menjadi pendamping mandor perawatan adalah kekurangan tenaga kerja. Tenaga kerja yang digunakan dalam pekerjaan ini hanya berjumlah tiga orang dan usia pekerja sudah memasuki umur 50 tahun sehingga pekerjaan tidak dapat diselesaikan dalam satu hari. Selain itu, pekerja sering menggunakan bahan yang berlebihan. Menurut salah satu pekerja, dengan menggunakan bahan yang berlebihan akan menyebabkan gulma lebih cepat mati.

Pendamping mandor pupuk. Saat menjadi pendamping mandor pupuk, penulis ikut membantu mandor pupuk dalam memetakan aplikasi yang sudah selesai dipupuk. Penulis juga membantu mandor pupuk membuat bukti permintaan dan pengeluaran barang dalam hal permintaan pupuk dari gudang sentral kebun serta mengawasi dalam hal pengambilan pupuk di gudang. Penulis menghitung jumlah karyawan yang hadir dalam menentukan luasan lahan yang akan dipupuk, mengawasi jalannya pemupukan di lapangan, memeriksa aplikasi pemupukan dan mengisi laporan kerja dalam buku mandor. Rata- rata jumlah pekerja yang diawasi sebanyak 7 orang dengan luasan 30 ha.

Permasalahan yang dihadapi saat penulis menjadi pendamping mandor pemupukan adalah dosis yang diberikan belum sesuai dengan rekomendasi. Selain itu, seringkali pupuk tercecer di jalan pikul. Pekerja enggan mengeruk kembali pupuk yang telah tercecer. Hal ini dikarenakan pekerja tergesa-gesa dalam mengejar target. Dengan demikian, kualitas pekerja belum dapat dikatakan baik.

Kerani produksi. Saat penulis bertugas sebagai pendamping kerani produksi, penulis membantu dalam mencatat jumlah TBS yang terangkut per blok, per tahun tanam, kemudian membantu dalam pengumpulan dan pengangkutan TBS dari lapangan ke PKS agar terangkut dengan baik sehingga tidak ada buah yang restan/tertinggal di lapangan. Penulis juga membantu dalam membuat laporan produksi harian ke kantor Afdeling. Rata-rata jumlah pekerja yang diawasi sebanyak 3 orang dengan luasan +70 ha.

Kerani afdeling. Saat penulis bertugas sebagai pendamping kerani afdeling, penulis bertugas dalam menyusun laporan pekerjaan seperti : monitoring hasil panen, peta kerja, daftar premi, daftar lembur, dan permintaan bon minyak. Selain itu penulis juga membuat rencana kerja harian dan bulanan di Afdeling.

\section{Karyawan Staff}

Pendamping asisten lapang. Kegiatan penulis sebagai pendamping asisten lapang yakni memastikan kehadiran karyawan tiap kemandoran, melakukan pengawasan terhadap mandor, kontrol lapangan. Kemudian membantu assisten dalam menyusun rencana anggaran kerja Afdeling (harian, bulanan, dan tahunan) kepada atasan untuk dievaluasi. Rata-rata jumlah mandor yang diawasi sebanyak tiga orang dan jumlah krani produksi sebanyak dua orang.

\section{HASIL DAN PEMBAHASAN}

Praktik pemupukan memberikan kontribusi yang sangat luas dalam meningkatkan produksi dan kualitas produk yang dihasilkan. Berdasarkan anggaran budget, pemupukan di perkebunan sawit memerlukan biaya yang paling besar $\pm 70 \%$ dari biaya pemeliharaan. Oleh karena itu, strategi pemupukan harus mengacu pada konsep keefektifan dari segi manajemen pemupukan. 
Tepat

Tepat jenis. Pahan (2010) menyatakan bahwa strategi dalam menentukan jenis pupuk diwarnai oleh pertimbangan teknis dan pertimbangan ekonomis. Pertimbangan teknis meliputi sifat pupuk dan sifat tanah, dimana pupuk yang diaplikasikan akan sangat menentukan efisiensi pemupukan.

Berdasarkan pengamatan yang penulis lakukan, jenis pupuk yang digunakan di perkebunan sawit sesuai dengan rekomendasi pemupukan yang telah telah dibuat oleh bagian Departemen riset First Resources, Ltd. Rekomendasi pemupukan dibuat berdasarkan hasil analisis tanah dan analisis daun. Jenis pupuk yang diaplikasikan berdasarkan rekomendasi pemupukan perkebunan sawit pada tahun 2012 menggunakan pupuk tunggal. Oleh karena itu, dapat dikatakan bahwa jenis pupuk yang digunakan oleh perkebunan sawit telah memenuhi prinsip tepat jenis. Jenis pupuk yang digunakan di perkebunan sawit dapat dilihat pada Tabel 2.
Tabel 2. Jenis Pupuk yang Digunakan di Tambusai Estate Tahun 2011-2012

\begin{tabular}{lllc}
\hline \multirow{2}{*}{ Unsur hara } & \multirow{2}{*}{ Jenis pupuk } & \multicolumn{2}{c}{ Kandungan } \\
\cline { 3 - 4 } & & Unsur & $\%$ \\
\hline Nitrogen $(\mathrm{N})$ & Urea & $\mathrm{N}$ & 46 \\
Kalium (K) & MOP & $\mathrm{K}_{2} \mathrm{O}$ & 60 \\
Fosfor (F) & Rock Phosphate & $\mathrm{P}_{2} \mathrm{O}_{5}$ & 33 \\
Magnesium $(\mathrm{Mg})$ & Kieserit & $\mathrm{MgO}$ & 36 \\
Boron (B) & Borate & $\mathrm{B}_{2} \mathrm{O}_{3}$ & 48 \\
\hline Sumber:
\end{tabular}

Sumber: hasil pengamatan penulis (April,2012)

\section{Tepat Waktu}

Adiwiganda (2007) menyatakan bahwa waktu dan frekuensi pemupukan ditentukan oleh keadaan iklim terutama curah hujan dan hari hujan, sifat fisik tanah, kondisi relief, dan proses pengadaan pupuk. Curah hujan merupakan salah satu faktor yang mempengaruhi keefektifan pemupukan. Tambusai Estate melakukan aplikasi pemupukan sebanyak dua kali aplikasi yaitu semester pertama (Januari-Juni) dan semester kedua (JuliDesember)

Tabel 4. Realisasi Waktu Pemupukan di Tambusai Estate Juni 2011 - Mei 2012

\begin{tabular}{|c|c|c|c|c|c|c|c|c|c|c|c|c|}
\hline Jenis & & & & & & & & & & & & \\
\hline Pupuk & Juni & Jul & Ags & Sep & Okt & Nov & Des & Jan & Feb & Mar & Apr & Mei \\
\hline Urea & & & $* *$ & $* *$ & $* *$ & $* *$ & $* *$ & & & $*$ & $*$ & * \\
\hline MOP & $*$ & $* *$ & & $* *$ & $* *$ & $* *$ & $*$ & $*$ & $*$ & $*$ & * & \\
\hline $\mathrm{RPH}$ & & & & & & & * & * & $*$ & $*$ & $*$ & \\
\hline Kieserit & & & & & & & & $*$ & $*$ & * & $*$ & \\
\hline
\end{tabular}

Sumber : Kantor Sentral Kebun, PT. Panca Surya Agrindo (April, 2012)

Keterangan: * Aplikasi pupuk pertama

** Aplikasi pupuk kedua

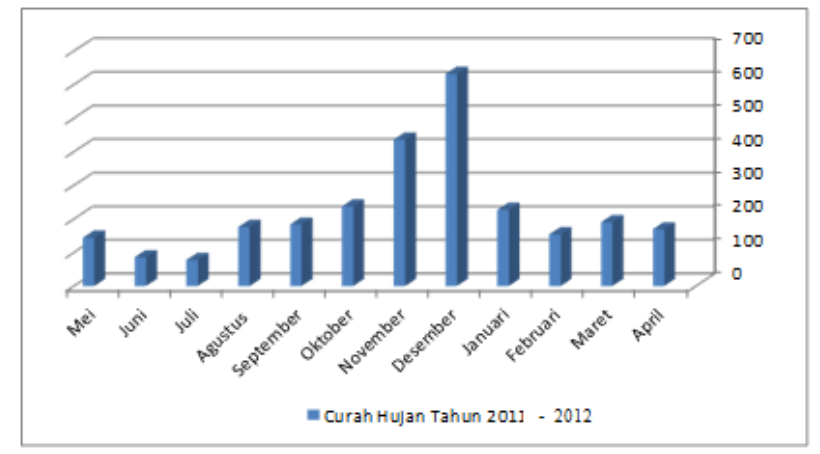

Gambar 1. Grafik Curah Hujan Tambusai Estate Periode Mei 2011-April 2012

Berdasarkan Tabel 4. Realisasi pemupukan di perkebunan ini dilakukan pada sepanjang bulan Juni 2011 hingga Mei 2012.
Aplikasi pemupukan di Tambusai Estate tetap dilakukan pada saat curah hujan tinggi (>300 $\mathrm{mm}$ ), yakni berada pada bulan November dan Desember. Hal ini dikarenakan pemupukan disesuaikan dengan ketersediaan pupuk yang ada di gudang pupuk. Oleh karena itu, dapat dikatakan bahwa realisasi waktu pemupukan di Tambusai Estate belum memenuhi prinsip kaidah tepat waktu.

\section{Tepat Cara}

Menurut PPKS (2003) penempatan pupuk juga berpengaruh terhadap hasil TBS. Cara pemupukan yang direkomendasikan oleh PPKS berdasarkan hasil-hasil penelitian yang telah dilakukan adalah dengan cara menabur pupuk $(\mathrm{N}$, 
Bul. Agrohoerti 3 (2): 177-184 (2015)

$\mathrm{P}, \mathrm{K}, \mathrm{Mg}$ ) secara merata di piringan pada jarak 1.5

$\mathrm{m}$ dari pangkal batang ke arah pinggir piringan.

Tabel 5. Ketepatan Cara Penaburan Pupuk di Afdeling 10

\begin{tabular}{|c|c|c|c|c|c|c|c|c|c|}
\hline \multirow{2}{*}{ Blok } & \multirow{2}{*}{$\begin{array}{l}\text { Tahun } \\
\text { Tanam }\end{array}$} & \multirow{2}{*}{ Jenis Pupuk } & \multirow{2}{*}{$\begin{array}{c}\text { Dosis } \\
(\mathrm{kg} / \mathrm{pkk})\end{array}$} & \multicolumn{5}{|c|}{ Rataan jarak tanam ke pokok $(\mathrm{cm})$} & \multirow{2}{*}{ Rata $(\mathrm{cm})$} \\
\hline & & & & 1 & 3 & 5 & 7 & 9 & \\
\hline W12 & 2005 & Kieserite & 0.75 & 150.2 & 142.7 & 140.1 & 135.0 & 163.2 & 146.24 \\
\hline W13 & 2005 & Kieserite & 0.75 & 141.9 & 137.8 & 144.3 & 142.5 & 142.1 & 141.72 \\
\hline V11 & 1997 & Kieserite & 1.25 & 126.7 & 129.2 & 140.4 & 143.5 & 131.0 & 134.16 \\
\hline Rata-rata & & & & & & & & & 140.70 \\
\hline
\end{tabular}

Sumber : Hasil Pengamatan Penulis (April, 2012)

Berdasarkan hasil pengamatan tepat cara diatas, diketahui bahwa rata-rata ketepatan cara dari penabur sebesar $140.706 \mathrm{~cm}$. Hal ini telah membuktikan bahwa pemupukan di Tambusai Estate telah memenuhi konsep tepat cara dan telah mendekati dengan rekomendasi perusahaan (1.5 $\mathrm{m})$.

\section{Tepat Dosis}

Tabel 6. Pengamatan Ketepatan Dosis Pupuk di Tambusai Estate

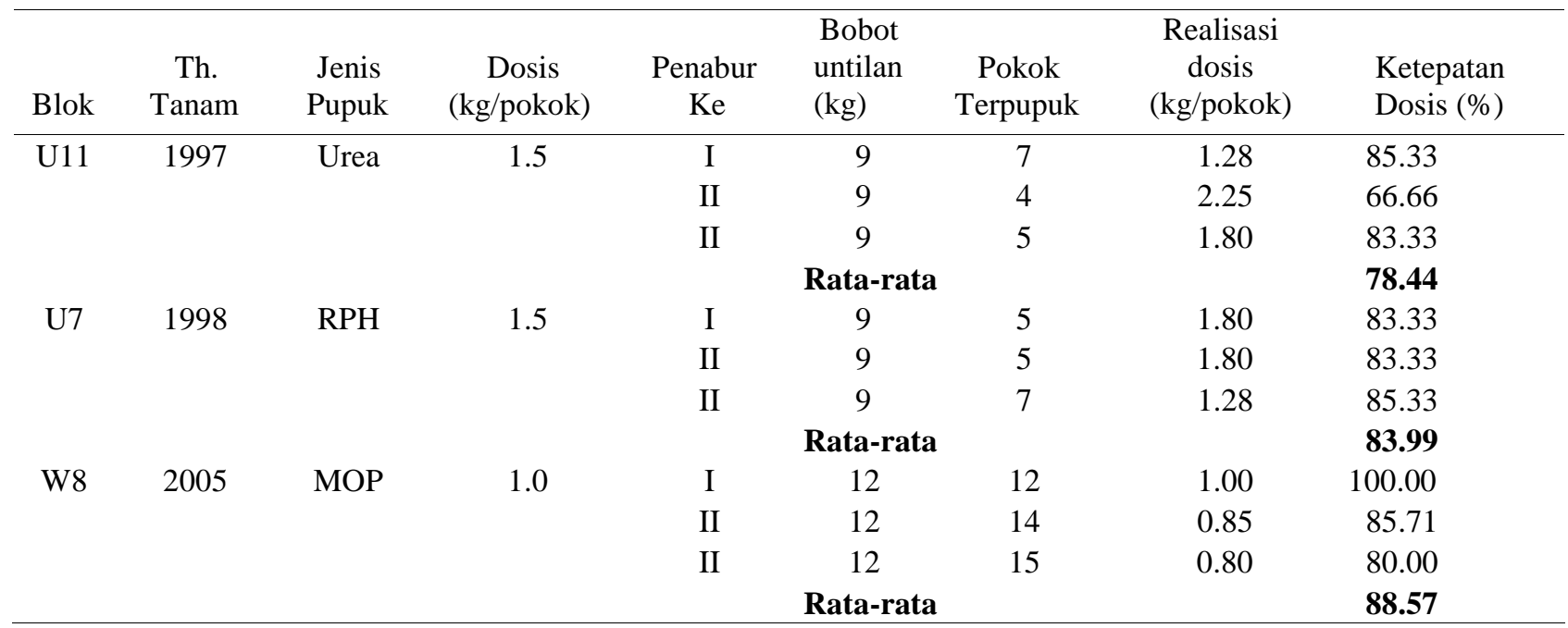

Sumber : Hasil Pengamatan Penulis (Maret, 2012)

Pekerja penabur menggunakan mangkok yang seragam dalam hal menabur pupuk untuk berbagai jenis pupuk. Pada perkebunan sawit tidak ada standar baku ukuran takaran untuk tiap dosis per pokok. Hal ini menyebabkan pekerja hanya mengira-ngira dosis ( $\mathrm{kg} /$ pokok).

Berdasarkan data pengamatan di atas ratarata ketepatan dosis pemupukan Urea dan RPH untuk dosis $1.5 \mathrm{~kg} /$ pokok sebesar $78.44 \%$ dan $83.99 \%$, dan rata-rata ketepatan dosis pemupukan MOP untuk dosis $1.0 \mathrm{~kg} /$ pokok sebesar $88.57 \%$. Padahal menurut SOP pemupukan di perkebunan sawit, ketepatan dosis pemupukan harus berada di atas $95 \%$. Oleh karena itu, dapat dikatakan bahwa ketepatan dosis aplikasi pemupukan di perkebunan sawit belum memenuhi prinsip kaidah tepat dosis.
Menurut PPKS (2003) pertimbangan yang digunakan dalam penentuan dosis pupuk berguna untuk mengimbangi kekurangan hara yang ada didalam tanah meliputi hasil pengamatan lapangan seperti gejala defisiensi hara, kultur teknis, dan panen. Pengamatan ketepatan dosis pemupukan disajikan pada Tabel 6 . a-rata

\section{Pemupukan Mekanis dengan Fertilizer Spreader}

Dalam meningkatkan keefektifan pemupukan, perkebunan sawit melakukan pemupukan secara mekanis dengan menggunakan fertilizer spreader. Fertilizer spreader merupakan alat yang digunakan untuk mengaplikasikan pupuk ke tanaman kelapa sawit pada areal tanaman yang sudah menghasilkan dari lahan yang datar sampai bergelombang dengan kemiringan $0-5^{0}$.

Sebelum aplikasi fertilizer spreader dilakukan, seorang mandor dan asisten sebaiknya memperhatikan kebersihan areal dari gulma yang terdapat di antara pokok kelapa sawit. Berdasarkan kenyataannya di lapangan, penulis 
menemukan areal yang terdapat di antara pokok sawit belum sepenuhnya bersih dari gulma.

Aplikasi pemupukan dimulai dengan menyiapkan pupuk di gudang afdeling kemudian dibawa dengan truk untuk diecer ke lahan aplikasi. Traktor dan Emdek digabungkan menjadi satu dengan posisi emdek dibagian belakang traktor. Setelah pupuk diecer dilahan aplikasi, pupuk diletakkan di pinggir areal tanaman. Hal ini bertujuan untuk memudahkan proses pemupukan dengan menggunakan penabur pupuk.

Setelah fertilizer spreader diisi oleh pupuk sebanyak $400 \mathrm{~kg}$, maka pemupukan segera dimulai. Traktor bergerak melewati jalan pikul pertama, kemudian yang kedua dan seterusnya hingga jalan pikul ke delapan. Setelah itu, fertilizer spreader diisi lagi dengan pupuk sebanyak $400 \mathrm{~kg}$ kemudian pemupukan dilanjutkan pada jalan pikul ke sembilan hingga jalan pikul ke-16 dan seterusnya (1 jalan pikul berisi 50 pokok).
Perbandingan Efisiensi Pemupukan secara Manual dan secara Mekanis dengan Fertilizer Spreader

Berdasarkan hasil pengamatan yang penulis lakukan, aplikasi pemupukan yang dilakukan secara mekanis menghasilkan mutu yang lebih baik daripada pemupukan secara manual, yakni sebaran pupuknya lebih merata dan seragam. Pada pemupukan manual seringkali terdapat pupuk dalam bentuk bongkahan saat penaburan ke lapang. Akan tetapi untuk pupuk yang disebar dengan fertilizer spreader tidak ada yang berbentuk bongkahan karena semuanya sudah melewati proses penyaringan sehingga kehilangan pupuk jauh lebih kecil daripada pemupukan secara manual. Perbedaan keefisienan pemupukan berdasarkan cara aplikasinya dapat penulis sajikan pada Tabel 7.

Tabel 7. Perbandingan Efisiensi Pemupukan secara Manual dan Mekanis

\begin{tabular}{lll}
\hline \multicolumn{1}{c}{ Uraian } & \multicolumn{1}{c}{ Pemupukan secara Manual } & \multicolumn{1}{c}{$\begin{array}{c}\text { Pemupukan secara Mekanis } \\
\text { (dengan Fertilizer Spreader) }\end{array}$} \\
\hline $\begin{array}{l}\text { Biaya pemupukan per-hektar } \\
\text { Pemadatan Tanah }\end{array}$ & Lebih tinggi (Rp 361 976. 23) & Lebih rendah ( Rp 359 316. 37) \\
Persyaratan Areal & Tidak Terjadi & Terjadi \\
Tenaga Kerja & Terjangkau di semua medan & Terbatas, kemiringan 0-5 \\
Kualitas Aplikasi & Banyak & Sedikit (Cukup 3 orang) \\
Pengawasan & Tidak Seragam & Seragam \\
Pertumbuhan Gulma & Intensif & Tidak Intensif \\
\hline
\end{tabular}

Sumber : Hasil Pengamatan Penulis (Maret, 2012)

Kegiatan pemupukan secara mekanis dengan fertilizer spreader di Tambusai Estate menunjukkan bahwa penyebaran pupuk yang lebih merata dan sistem pengawasan pemupukan secara mekanis tidak se-intensif pemupukan secara manual.

\section{Defisiensi Hara}

Tabel 8. Pengamatan Gejala Defisiensi Hara di Lima Blok

\begin{tabular}{lrrrrrrr}
\hline \multirow{2}{*}{ Defisiensi hara } & \multicolumn{4}{c}{ Blok } & \multicolumn{3}{c}{$\begin{array}{c}\text { Jumlah tanaman } \\
\text { defisiensi }\end{array}$} \\
\cline { 2 - 9 } & V11 & V10 & V8 & V10 & R3 & & taman Defisiensi \\
\hline $\mathrm{N}$ & 0 & 0 & 0 & 0 & 0 & 0 & $0 \%$ \\
$\mathrm{P}$ & 11 & 10 & 13 & 5 & 4 & 53 & $3.21 \%$ \\
$\mathrm{~K}$ & 73 & 100 & 113 & 102 & 130 & 518 & $31.4 \%$ \\
$\mathrm{Mg}$ & 21 & 45 & 48 & 70 & 105 & 289 & $17.5 \%$ \\
$\mathrm{~B}$ & 24 & 27 & 18 & 5 & 19 & 93 & $5.63 \%$ \\
$\mathrm{Fe}$ & 10 & 21 & 29 & 6 & 13 & 79 & $4.78 \%$ \\
\hline Total & & & & & & 1032 & $62.54 \%$ \\
\hline
\end{tabular}

Pengamatan gejala defisiensi hara dilakukan secara sistematis mulai dari jalan pikul ke- $10,20,30,40$, dan 50 pada 5 blok yaitu blok V11, V10, V8, W10, R3 dengan mengambil 330 tanaman/blok dengan total sampel sebanyak \pm 1650 tanaman. Penulis melakukan pengamatan secara visual dari gejala-gejala yang muncul di tanaman. Hasil pengamatan gejala visual defisiensi hara dapat dilihat pada Tabel 8 .

Sumber : Hasil Pengamatan Penulis (Maret-April, 2012) 
Berdasarkan pengamatan visual defisiensi hara yang dilakukan oleh penulis pada blok V11, V10, V8, W10, dan R3 seperti pada tabel di atas, dari 1650 tanaman sampel yang diamati, dapat diketahui bahwa jumlah tanaman contoh yang kekurangan hara adalah $62.54 \%$ dari total tanaman contoh, sedangkan defisiensi hara terbanyak adalah hara Kalium (31.4\%), diikuti defisiensi hara Magnesium (17.5\%), defisiensi hara Boron $(5.63 \%)$, defisiensi hara $\mathrm{Fe}(4.78 \%)$, dan defisiensi hara $\mathrm{P}$ (3.21\%). Penulis tidak menemukan tanaman yang mengalami defisiensi hara $\mathrm{N}$ pada tanaman contoh. Pada umumnya tanaman yang mengalami defisiensi hara $\mathrm{N}$ dapat dijumpai pada areal-areal rendahan dan cukup tergenang, seperti daerah rawa atau areal-areal blok yang rawan banjir.

\section{KESIMPULAN}

Kegiatan magang yang penulis lakukan telah meningkatkan pengetahuan tentang budidaya tanaman kelapa sawit, memperoleh pengalaman dan keterampilan kerja sebagai KHL, pendamping mandor, dan pendamping field assistant dalam pengelolaan kebun kelapa sawit baik secara teknis maupun manajerial, khususnya dalam aspek manajemen pemupukan.

Dalam mencapai produksi yang optimal perlu memperhatikan prinsip pemupukan yang terdiri dari $4 \mathrm{~T}$, yaitu: tepat jenis, waktu, dosis, dan cara. Untuk kriteria ketepatan jenis pupuk sesuai dengan jenis kebutuhan hara yang diperlukan oleh tanaman. Untuk kriteria ketepatan waktu pemupukan di perkebunan sawit belum berlangsung dengan baik. Kemunduran jadwal pemupukan terjadi karena belum tersedianya pupuk di kebun. Untuk kriteria tepat dosis pemupukan belum tercapai. Hal ini dapat dilihat masih banyaknya tanaman yang mengalami gejala defisiensi hara. Untuk kriteria cara dan tempat pemupukan di Tambusai Estate secara umum sudah berlangsung baik.

Kegiatan pemupukan secara mekanis dengan fertilizer spreader di Tambusai Estate menunjukkan bahwa hasil pekerjaan jauh lebih efektif dan lebih efisien daripada pemupukan secara manual.

\section{DAFTAR PUSTAKA}

Adiwiganda, R. 2007. Manajemen tanah dan pemupukan perkebunan kelapa sawit, hal. 19-118. Dalam S. Mangoensoekarjo (Ed.). Manajemen Tanah dan Pemupukan Budidaya Perkebunan. Gadjah Mada University Press. Yogyakarta.

Budiyanto, S. Mujiharjo, N. Aprianto. 2005. Kajian perbedaan tandan buah segar yang dihasilkan oleh perkebunan rakyat dan perkebunan besar. Jurnal Akta Agronesia. 8 (1) : 36-40.

[Ditjenbun] Direktorat Jendral Perkebunan. 2011. Ekspor Produk Kelapa Sawit Terus Naik. http://ditjenbun.deptan.go.id/index.php/com ponent/content/article/36-news/203-eksporproduk-kelapa-sawit-terus-naik.html [30 Januari 2012].

[Ditjenbun] Direktorat Jendral Perkebunan. 2011. Luas Perkebunan dan Produksi Kelapa Sawit di Seluruh Indonesia. www.ditjenbun.deptan.go.id/index.php/ teknik-budidaya.html. [ 30 Januari 2012].

Pahan, I. 2010. Panduan Lengkap Kelapa Sawit. Penebar Swadaya. Jakarta.

Poeloengan, Z., M. I. Fadli, Winarna, S. Rahutomo, dan E. S. Sutarata. 2003. Permasalahan pemupukan pada perkebunan kelapa sawit, hal 67-80. Dalam W. Darmosarkoro, E. S. Sutarta, dan Winarna $(E d s)$. Lahan dan Pemupukan Kelapa Sawit. Medan.

PPKS. 2003. Budidaya Kelapa Sawit. Pusat Penelitian Kelapa Sawit. Medan. 140 hal.

Siregar, A. Z. 2006. Kelapa Sawit : Minyak Nabati Berprospek Tinggi. Universitas Sumatera Utara. Medan. 